\title{
INFLUENCE OF VISCOSITY MODIFYING AGENT ON SOME RHEOLOGICAL PROPERTIES, SEGREGATION RESISTANCE AND COMPRESSIVE STRENGTH OF SELF-COMPACTING CONCRETE
}

\author{
Anna M. Grabiec \\ Department of Theory of Structures and Agricultural Building Engineering, \\ Faculty of Land Reclamation and Environmental Engineering, University of Life Sciences, Poznan, Poland \\ E-mail: agra@up.poznan.pl \\ Received 31 Jan. 2012; accepted 10 Aug. 2012
}

\begin{abstract}
Rheological properties of self-compacting concrete mixes containing a viscosity modifying agent (VMA) in their composition were studied. After preliminary studies self-compacting concrete mixes and, particularly, a fluid concrete mix prone to segregation of its ingredients were chosen. VMA was added in various amounts to that concrete mix to check how it performed in fresh and hardened concrete. Main studies focused on the influence of VMA on the following properties of concrete mixes: the slump flow, the flow time into the diameter of $500 \mathrm{~mm}$ and the resistance to segregation in the vertical direction. Moreover, the air content of concrete mixes and the 28-day compressive strength of concrete were measured. Test results showed that VMA significantly influenced the rheological properties of concrete mix, stabilised it and reduced the segregation. It was proved, that the concrete mix modified by VMA used in the optimal amount, featured the smallest scatter of concrete strength results. Besides, the Tukey's test showed that a reduction of the concrete compressive strength is possible to be statistically insignificant when compared to the reference level.
\end{abstract}

Keywords: self-compacting concrete, viscosity modifying agent, rheological properties, segregation resistance.

\section{Introduction}

Self-compacting concrete (SCC) is one of the newest achievements in concrete technology. It is the result of research on enhanced durability of concrete carried out by Japanese scientists (Okamura, Ouchi 1999). Despite that SCC is one of the newest concrete types, one can already talk about its history due to the intensity of testing and a broad range of its application over the past two decades. These, however, vary greatly. The progress is very significant in Japan, USA, Canada and the majority of European countries, including Poland. It not only concerns studies of rheological properties of SCC mixes (e.g., Szwabowski, Gołaszewski 2010) but their microstructure (LaźniewskaPiekarczyk, Szwabowski 2010), the pore structure (Gorzelańczyk, Hoła 2011) and the influence of moisture content on the compressive destruction process in SCC subjected to a multiply changing load (Gorzelańczyk 2011). On the other hand, this progress is smaller in the Middle East, except for a few spectacular high-rise structures in Dubai, where SCC was used (Umar, Al-Tamimi 2011). The European document prepared by European Federation Suppliers of Specialist Construction Chemicals specifying standards corresponding to SCC is The European Guidelines for Self-Compacting Concrete (EFNARC 2005). Specification. Production and Use, including the newest issue of 2005. Additionally, EFNARC issued The Guidelines for Viscosity Modifying Admixtures for Concrete (EFNARC 2006), where Chapter 5 is devoted to SCC.
Regarding SCC mixes, two essential properties are required, i.e. filling ability (including passing ability through reinforcing bars) and resistance to segregation. In the basic version, in order to fulfil these conditions, one must choose main mix components (cement - microfiller superplasticiser - water) in such a way that the assumed rheological properties are achieved. It is also possible to apply an additional component to control the internal integrity of the concrete mix. This component is called the viscosity modifying agent (VMA) or the viscosity enhancing agent (VEA). VMA/VEA increases the viscosity of cement paste without any reduction of water amount or any increase of the dust fraction amount (Woyciechowski 2006). There are three mechanisms of VMA action (Khayat, Ghezal 2003):

- adsorption - long polymer chains are connected with water molecules adsorbing some part of mix water and increasing their volume, what results in a viscosity increase of water and the concrete mix itself;

- association - molecules of adjacent polymer chains exhibit an attractive force, what reduces the mobility of water molecules and leads to the formation of gel, thus increasing the viscosity;

- splicing - at a low shear velocity and a large concentration of the polymer its chains can splice and inter-twist increasing the apparent viscosity, with the increasing shear rate the splices can get loose and disconnect reducing the shear resistance. 
An efficient VMA should ensure satisfactory plastic viscosity of a concrete mix, i.e. enable balancing of apparently contradictory properties - flowability, ability to fill small volumes and resistance to segregation. In the case of SCC, due to its significant fluidity, VMA should first of all protect the mix from the component segregation. This process is both dynamic (phenomena during concrete placing - changes of reinforced concrete element cross-section, obstacles in the form of rebars) and static (phenomena after concrete placing - aggregate sedimentation due to various density of concrete mix components). The segregation negatively influences many properties of hardened concrete, including physical parameters (water absorption, frost resistance) as well as the uniformity of compressive strength (Woyciechowski 2006) in extreme cases.

Viscosity modifying agents are used in the form of water soluble polymers increasing the viscosity of concrete mix (cellulose ethers, starch, polyvinyl alcohols), water soluble flocculants increasing attractive forces between cement grains by adsorption (natural resins, styrene and carboxyl polymers), organic emulsions (e.g. acrylics) introducing additional small particles to the mix (Khayat, Ghezal 2003), extra fine inorganic materials featuring high binding, e.g. bentonite, silica fume and some types of fly ash (Lachemi et al. 2004a; Leemann, Winnefeld 2007; Rols et al. 1999; Woyciechowski 2006). A limited use of viscosity modifying agents in the SCC technology results from their relatively high price. It especially concerns synthetic viscosity modifying agents. VMA in the form of waste materials are much less known but they are promising due to their economic and ecological aspect. For example, Memon et al. (2011) reports the use of rice husk ash, an agro-industry waste product, as a usable VMA in the SCC technology, reducing costs and providing a method for its environment friendly disposal. Some economic and ecological accents are also found in the works by Lachemi et al. (2004b) and Grzesiak (2008). Testing of VMA influence on SCC is focused mainly on its performance with respect to rheological properties (Lachemi et al. 2004b; Leemann, Winnefeld 2007; Memon et al. 2011; Umar, Al-Tamimi 2011). In most cases an enhancement of rheological parameters is confirmed but this effect depends on the chemical composition of viscosity modifying agent (Gołaszewski, Cygan 2008, 2010; Hibino 2000; Łaźniewska-Piekarczyk, Szwabowski 2010; Łaźniewska-Piekarczyk 2011), the amount of VMA used, the water-binder ratio as well as the amount of superplasticiser which interacts in the synergy, what makes general conclusions difficult to formulate. The intensity of research on the influence of VMA on strength parameters in short-term and long-term hardening aspect (Memon et al. 2011; Panesar, Shindman 2011; Umar, Al-Tamimi 2011) is growing. Recently some experiments on VMA influence on early shrinkage of SCC composites (Gołaszewski, Cygan 2011), drying shrinkage, as well as, in one instance, on hydration process (Leemann, Winnefeld 2007) were carried out.

In the present study, SCC mixes were produced including viscosity modifying agent. The effect of the
VMA on the slump flow, the flow time into the diameter of $500 \mathrm{~mm}$, their changes versus time, segregation in the vertical direction and the air content of concrete mix are discussed. In addition, the influence of the VMA on the 28-day compressive strength of hardened concrete is analysed. The testing methods of the rheological properties according to EFNARC (2005) were used. These include the Abrams cone in the inverted version, the method to test concrete mix segregation modified by MC Bauchemie and European standard measurements of air content and compressive strength. In order to assess the influence of the VMA amount on concrete compressive strength the variance analysis was carried out.

\section{Experimental}

\subsection{Constituent materials}

Polish commercial Portland cement CEM I 42.5N-HSR/ NA with high sulphate resistance conforming to the Polish standard PN-B 19707:2003 was used. Some characteristics of the cement according to the information provided by the manufacturer are given in Table 1. Washed sand $(0 / 0.5 \mathrm{~mm}-15 \%)$, pit sand $(0.5 / 2 \mathrm{~mm}-85 \%)$ and gravel $(2 / 8 \mathrm{~mm}-50 \%$ and $8 / 16 \mathrm{~mm}-50 \%)$ as an aggregate and the tap water were used to produce the concrete mixes. Fly ash (ignition loss $-3.05 \%$; fineness measured according to EN 451-2 - 23.7\%; $\mathrm{Cl}^{-}-0.01 \% ; \mathrm{SO}_{3}-0.43 \%$; free lime $0.12 \%$; 28 -day pucolane activity factor $-79 \%$ ) was selected as a micro-filler. The superplasticiser with a polycarboxylate basis served as a fluidifying admixture $(\mathrm{pH}-6$, specific density $-1.10 \mathrm{~kg} / \mathrm{dm}^{3}$, recommended dosage $0.2-1.6 \%$, solid content $-30 \%$ ). A novel commercial VMA (pH approximately neutral as $1 \%$ solution, viscosity $-3000 \div 6000 \mathrm{mPa} \cdot \mathrm{s}$, recommended dosage $-0.01 \div$ $0.15 \%$ ) was chosen to modify concrete mixes. The chemical composition of the VMA is classified by the manufacturer. According to the available data it is a water soluble biopolymer, white to tan in appearance, produced by fermentation process.

Table 1. Composition, physical and mechanical properties of cement used

\begin{tabular}{l|c}
\hline \multicolumn{1}{c}{ Characteristic } & Result \\
\hline $\mathrm{Ch}^{\prime}$ & 2.78 \\
\hline $\mathrm{SO}_{3}$ & 0.048 \\
\hline $\mathrm{Cl}^{-}$ & 3.71 \\
\hline $\mathrm{Al}_{2} \mathrm{O}_{3}$ & 0.45 \\
\hline $\mathrm{Na}_{2} \mathrm{O}_{\mathrm{eq}}$ & 0.39 \\
\hline Insoluble residue (\%) & 1.18 \\
\hline Ignition loss (\%) & \\
\hline Potential compounds (\%) & 61.6 \\
\hline $\mathrm{C}_{3} \mathrm{~S}$ & 14.9 \\
\hline $\mathrm{C}_{2} \mathrm{~S}$ & 14.9 \\
\hline $\mathrm{C}_{4} \mathrm{AF}$ & 1.5 \\
\hline $\mathrm{C}_{3} \mathrm{~A}$ & 295 \\
\hline Blaine's specific surface $\left(\mathrm{m}^{2} / \mathrm{kg}\right)$ & 205 \\
\hline Initial setting time (min) & 300 \\
\hline Final setting time (min) & 0.71 \\
\hline Volume stability (mm) & \\
\hline Compressive strength (MPa) & 21.9 \\
\hline 2 days & 52.5 \\
\hline 28 days & \\
\hline
\end{tabular}




\subsection{Assumptions and scope}

The main studies were aimed at checking the statement, that VMA would stabilise the concrete mix, make it more homogenous and not prone to segregation. The concrete mix was prepared according to the specification adopted in the preliminary studies. 15 concrete mixes, which composition had various values of the aggregate sand point and the amounts of fly ash and superplasticiser (Table 2) were prepared. The maximal diameter of slump-flow $\left(\mathrm{d}_{\max }\right)$, the flow time into the $500 \mathrm{~mm}$ diameter $\left(\mathrm{T}_{500}\right)$ and the air content were checked (Table 3 ). Basing on these preliminary studies the reference mixes No. 5 and No. 6 were selected. They fulfilled the selfcompacting criteria specified by the range limits of these parameters. In the view of the recommendations from EFNARC (2005) and some from the literature (Jin, Domone 2002; Felekoglu et al. 2003) the following ranges were adopted for the present study: $d_{\max }=650-800 \mathrm{~mm}$, $\mathrm{T}_{500}=2-6 \mathrm{~s}$ and the maximal air content $4.0-5.5 \%$. It should be pointed out that EFNARC recommendations (2005) concerning the maximal diameter of slump flow and the literature ones differ slightly. Moreover, according to EFNARC (2005), measurement of the time $T_{500}$ may be omitted if not requested. EFNARC (2005) does not specify any requirements concerning the air content in the concrete mix, either. Hence, the present author adopted the ranges individually but without any violation of upper and lower limits recommended in the sources related to the subject.

Within the scope of the preliminary testing a mix was selected, it was then subjected to the action of VMA in order to bring its properties as close as possible to those for the reference mixes. It was the mix No. 6 which composition was changed - the sand point was raised and the amounts of fly ash and superplasticiser increased. It was henceforth denoted by $\mathrm{X}$, it featured high fluidity and was potentially prone to an intensive segregation. It was modified with VMA applied in various amounts and the rheological properties, i.e. $d_{\max }, T_{500}$, the flow changes in time and the resistance to component segregation in the vertical direction were measured to assess the effectiveness of VMA. It was decided to adopt four levels of VMA amount, taking into account the recommendation by the manufacturer, limiting it to the range of $0.01-$ $0.15 \%$ with respect to the mix water amount. It was assumed, that the basic dosage of the VMA will be equal to the midpoint value of the recommended range. Having carried out the testing of the mix with this dosage it was found, that the amount should be decreased. It was done using the bisection rule. Hence, the following amounts of VMA emerged: $0.01 \%, 0.0275 \%, 0.045 \%$ and $0.08 \%$ with respect to the mix water amount.

The testing results of the rheological properties, the air content, the vertical segregation and the 28-day compressive strength for the concrete mix and hardened concrete without VMA (denoted in the preliminary testing stage by $\mathrm{X}$ and in the main testing by $\mathrm{C} 0$ ) were used as the reference results for concrete mixes and hardened concrete with the VMA addition (denoted in the main testing stage by $\mathrm{C} 0.01$; $\mathrm{C} 0.0275$; $\mathrm{C} 0.045$ and $\mathrm{C} 0.08$ according to the above mentioned amount of VMA).

The compressive strength results were subjected to the statistical analysis from the point of view of the influence of the VMA amount.

\subsection{Testing procedure of fresh and hardened concretes}

The components of self-compacting concrete were mixed using a paddle-type $0.06 \mathrm{~m}^{3}$ mixer. First, dry materials (cement, fly ash, aggregate) were mixed for 1 minute. Then $75 \%$ of the total amount of water was added and mixed for next 2 minutes. Finally, the remaining 25\% of

Table 2. Mix proportions of various concretes (preliminary studies)

\begin{tabular}{|c|c|c|c|c|c|c|c|c|c|}
\hline \multirow{2}{*}{$\begin{array}{l}\text { Designation } \\
\text { of concrete } \\
\text { mix recipe }\end{array}$} & \multicolumn{8}{|c|}{ Content of concrete mix constituents $\left(\mathrm{kg} / \mathrm{m}^{3}\right)$} & \multirow{2}{*}{$\begin{array}{c}\text { Sand } \\
\text { point } \\
(\%)\end{array}$} \\
\hline & Cement & Fly ash & $\begin{array}{c}\text { Sand } \\
0 / 0.5 \mathrm{~mm}\end{array}$ & $\begin{array}{c}\text { Sand } \\
0 / 2 \mathrm{~mm}\end{array}$ & $\begin{array}{c}\text { Gravel } \\
2 / 8 \mathrm{~mm}\end{array}$ & $\begin{array}{c}\text { Gravel } \\
8 / 16 \mathrm{~mm}\end{array}$ & $\begin{array}{c}\text { Super- } \\
\text { plasticiser }\end{array}$ & Water & \\
\hline 1 & 383 & $96(25)$ & $163(20)$ & $651(80)$ & $491(50)$ & $49(50)$ & $3.84(1,00)$ & 152 & 45 \\
\hline 2 & 400 & $80(20)$ & $182(20)$ & $729(80)$ & $438(50)$ & $438(50)$ & $4.00(1,00)$ & 157 & 50 \\
\hline 3 & 400 & $80(20)$ & $180(20)$ & $721(80)$ & $433(50)$ & $433(50)$ & $6.00(1,50)$ & 162 & 50 \\
\hline 4 & 400 & $80(20)$ & $181(20)$ & $725(80)$ & $436(50)$ & $436(50)$ & $6.40(1,60)$ & 158 & 50 \\
\hline 5 & 400 & $100(25)$ & $178(20)$ & $712(80)$ & $428(50)$ & $428(50)$ & $6.40(1,60)$ & 162 & 50 \\
\hline 6 & 383 & $115(30)$ & $159(20)$ & $635(80)$ & $479(50)$ & $479(50)$ & $6.14(1,60)$ & 158 & 45 \\
\hline 7 & 383 & $115(30)$ & $159(20)$ & $635(80)$ & $479(50)$ & $479(50)$ & $5.75(1,50)$ & 159 & 45 \\
\hline 8 & 383 & $115(30)$ & $159(20)$ & $635(80)$ & $479(50)$ & $479(50)$ & $5.37(1,40)$ & 159 & 45 \\
\hline 9 & 383 & $115(30)$ & $159(20)$ & $635(80)$ & $479(50)$ & $479(50)$ & $4.60(1,20)$ & 160 & 45 \\
\hline 10 & 383 & $115(30)$ & $159(20)$ & $635(80)$ & $479(50)$ & $479(50)$ & $3.84(1,00)$ & 160 & 45 \\
\hline 11 & 394 & $118(30)$ & $188(25)$ & $564(75)$ & $488(50)$ & $488(50)$ & $3.94(1,00)$ & 164 & 45 \\
\hline 12 & 383 & $115(30)$ & $115(15)$ & $651(83)$ & $493(50)$ & $493(50)$ & $3.83(1,00)$ & 160 & 45 \\
\hline 13 & 383 & $115(30)$ & $115(15)$ & $651(85)$ & $493(50)$ & $493(50)$ & $4.60(1,20)$ & 160 & 45 \\
\hline 14 & 383 & $96(25)$ & $117(15)$ & $663(85)$ & $501(50)$ & $501(50)$ & $4.79(1,25)$ & 156 & 45 \\
\hline 15 & 383 & $134(35)$ & $113(15)$ & $640(85)$ & $484(50)$ & $484(50)$ & $4.41(1,15)$ & 163 & 45 \\
\hline $\mathrm{X}$ & 400 & $160(40)$ & $168(20)$ & $673(80)$ & $404(50)$ & $404(50)$ & $8.80(2,20)$ & 169 & 50 \\
\hline
\end{tabular}

Note: the respective values in parentheses are: fly ash content and superplasticiser content with respect to the cement mass; $0 / 0.5 \mathrm{~mm}$ and $0 / 2 \mathrm{~mm}$ sand content in the total sand mass (100\%); $2 / 8 \mathrm{~mm}$ and $8 / 16 \mathrm{~mm}$ gravel amount in the total gravel mass (100\%) 

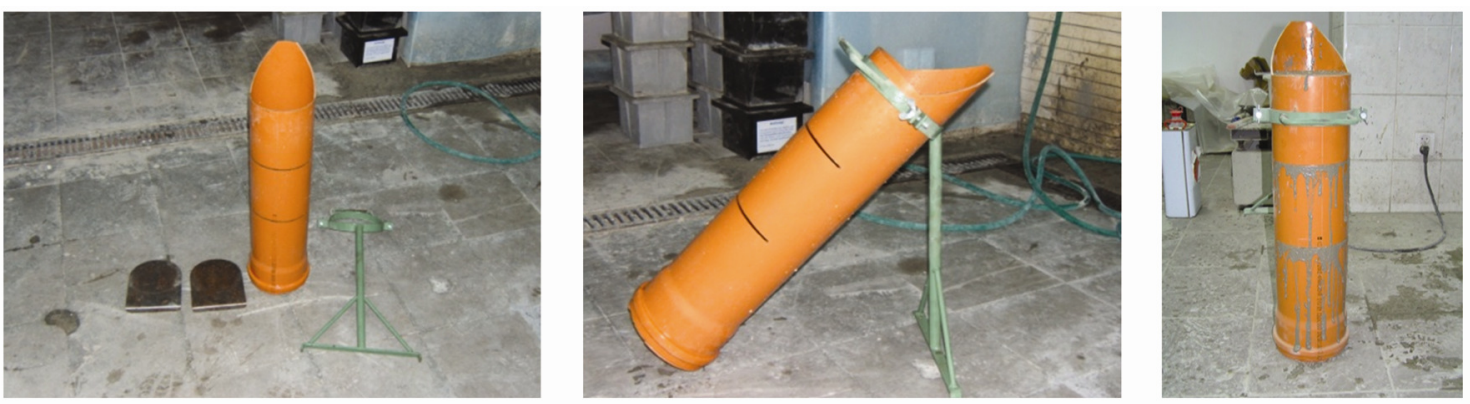

Fig. 1. Set evaluating resistance of SCC mixes to vertical segregation (Grabiec, Chutek 2008)

water was added with an appropriate amount of superplasticiser introduced beforehand and mixed for 3 minutes. In the case of concrete mixes with VMA, the latter was dissolved in the superplasticiser before mixing with $25 \%$ amount of water.

The slump flow of concrete mix was measured according to the method specified in EFNARC (2005). The fluidity of fresh concrete was indicated by the measured flow spread diameter in the inverted Abrams cone. In order to examine the changes in time of the flow value and dynamics of the flow, the flow value and $\mathrm{T}_{500}$ was measured after $0,15,30,45,60,75,90,105$ and 120 minutes from the mixing process. An assessment of rheological properties and mix homogeneity was also made by a macroscopic observation. The air content in fresh concrete was tested according to the method specified in the European standard EN 12350-7:2001. A 3-minute break was introduced for self-deaerating of the concrete mix.

The segregation resistance in the vertical direction was evaluated with the use of the method developed by MC Bauchemie, adopting the "Munich sedimentation test" for SCC developed in 2001 by the Institute of Building Materials Science and Testing in Munich (Lowke et al. 2003), applying a sedimentation column. Fresh concrete was poured into a plastic vessel $(\varnothing=150 \mathrm{~mm}$, $\mathrm{h}=495 \mathrm{~mm}$ ). The vessel had two thin cuts for placing metal sheets to divide the concrete mix sample into three parts (Fig. 1). After 20 minutes when the vertical movement of aggregate in the vessel was allowed, the dividers were placed in the cuts. The concrete mix from the upper, middle and bottom sections passed through an $8-\mathrm{mm}$ mesh screen, and the aggregate grains coarser than $8 \mathrm{~mm}$ were washed out from the sample. The coarse aggregate from three sections was dried and weighted. According to the MC Bauchemie recommendation, when the differences between the aggregate amounts in the upper, middle and bottom sections are lower than $20 \%$, there is no vertical segregation in the SCC mix (Grabiec, Chutek 2008). The compressive strength was evaluated using $150 \mathrm{~mm}$ concrete cubes. After removal from the moulds, the specimens were cured in water at $20^{\circ} \mathrm{C}$ until the time of testing, i.e. for 28 days. There were 6 specimens in each examined concrete series. The Statistica (Software program, licence from the University of Life Sciences, licence no: JGNP 105B037825 AR-A) was used for the statistical analysis referring to the compressive strength results. The level of the statistical significance was taken as $\alpha=0.05$. Within the analysis the Levene's test con- cerning the variance homogeneity was carried out. Then, followed one of available tests (Tukey's test) checking the statistical significance of differences in mean compressive strength values between assumed subclasses (levels) of the VMA amount was performed.

Table 3. Properties of fresh concretes (preliminary studies)

\begin{tabular}{c|c|c|c}
\hline \multirow{2}{*}{$\begin{array}{c}\text { Designation } \\
\text { of concrete } \\
\text { mix recipe }\end{array}$} & \multicolumn{3}{|c}{ Characteristic of concrete mix } \\
\cline { 2 - 4 } & $\begin{array}{c}\mathrm{d}_{\max } \\
(\mathrm{mm})\end{array}$ & $\begin{array}{c}\mathrm{T}_{500} \\
(\mathrm{~s})\end{array}$ & $\begin{array}{c}\text { Air content } \\
(\%)\end{array}$ \\
\hline 1 & $530 \times 550$ & 6.5 & 6.1 \\
\hline 2 & $600 \times 600$ & 6.0 & 5.5 \\
\hline 3 & $760 \times 760$ & 4.5 & 6.2 \\
\hline 4 & $750 \times 760$ & 6.0 & 6.5 \\
\hline 5 & $750 \times 750$ & 5.0 & 4.3 \\
\hline 6 & $790 \times 800$ & 4.5 & 3.4 \\
\hline 7 & $780 \times 800$ & 5.0 & 3.6 \\
\hline 8 & $780 \times 800$ & 5.0 & 3.5 \\
\hline 9 & $760 \times 780$ & 4.5 & 4.0 \\
\hline 10 & $690 \times 700$ & 5.0 & 8.0 \\
\hline 11 & $710 \times 720$ & 5.5 & 7.5 \\
\hline 12 & $620 \times 630$ & 8.5 & 5.8 \\
\hline 13 & $760 \times 770$ & 4.5 & 5.4 \\
\hline 14 & $740 \times 750$ & 5.5 & 8.2 \\
\hline 15 & $750 \times 760$ & 4.5 & 7.5 \\
\hline$X$ & $850 \times 850$ & 4.0 & 1.7 \\
\hline
\end{tabular}

\section{Test results and discussion}

The testing results of the rheological properties for the reference mix $\mathrm{C} 0$ were analogous to those from the preliminary studies for the concrete mix of the same composition, denoted by X. It proved that the mixes were repetitive an indicated that there was no randomness in the concrete mixing at both stages of studies.

The maximal slump flow diameter of concretes mixes, the flow time into the diameter of $500 \mathrm{~mm}$ and their changes in time are shown in Figs 2 and 3, respectively. The air content in fresh concrete and the 28-day compressive strength of hardened concrete are presented in Table 4 .

The results of the main studies proved, that VMA influenced significantly the rheological properties of the mix. An increase of the VMA amount led to a decrease of the maximal diameter of the slump flow (Fig. 2) and to an increase of the flow time into the diameter of $500 \mathrm{~mm}$ (Fig. 3). Therefore, it can be concluded, that the applied VMA increased the internal cohesion of the mix, positively modifying its rheological properties when com- 
pared with unsatisfactory values for the reference mix without VMA as far as the adopted admissible ranges of $\mathrm{d}_{\max }$ and $\mathrm{T}_{500}$ are concerned.

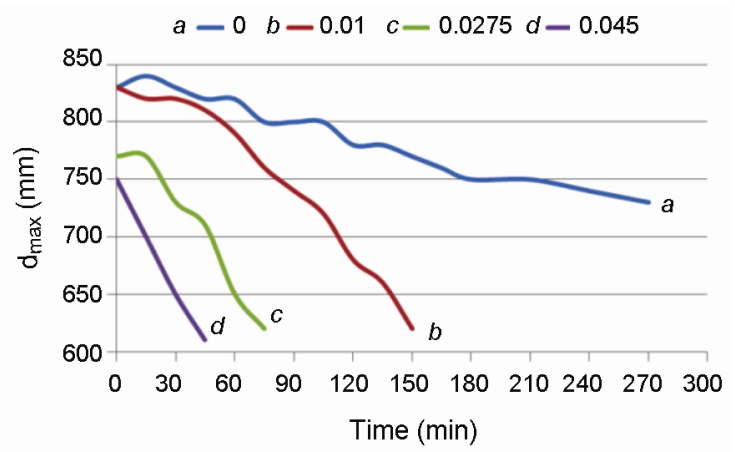

Fig. 2. Slump flow of SCC mixes versus time

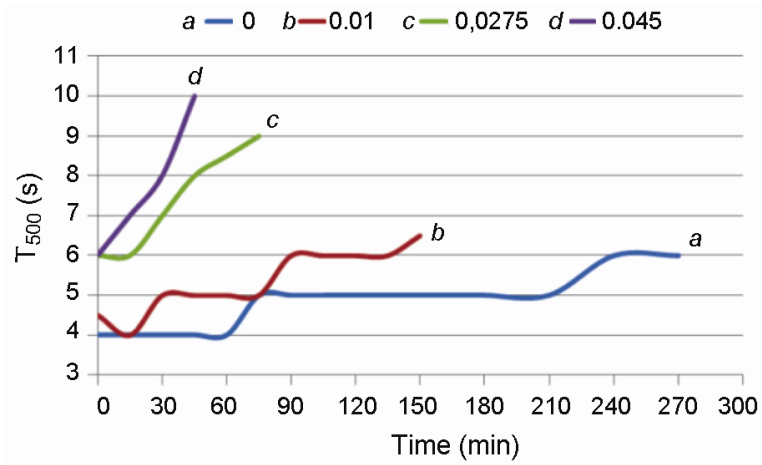

Fig. 3. Time of SCC mixes' flow into diameter of $500 \mathrm{~mm}$ versus time

Unfortunately, the VMA addition raised the air content in the concrete mix, which increased with increasing VMA amount (Table 4). In the case of SCC the selfdeaeration is vital, so this feature of VMA application, especially for the dosages higher than $0.0275 \%$, is unwanted. However, the literature data regarding the influence of VMA on the air content in concrete mixes vary. According to EFNARC (2006), the majority of viscosity modifying agents has little effect on concrete properties in fresh state but "some, if used at high dosage, can affect the content and stability of entrained air". Still, EFNARC (2006) does not specify the case of SCC. Umar and AlTamimi (2011), following EFNARC (2006), suggests, that VMAs, especially the cellulose based ones, do not change any properties of fresh SCC, including the air content. Lachemi et al. (2004b) reports a decrease of the air content in SCC mixes, greater with an increase of the polysaccharide-based VMA content. Therein the air content between $1.5 \%$ and $2.3 \%$ is assumed as adequate to maintain workability and flowability. In this context some care is necessary in stating any decisive conclusions, because certainly the chemical basis of VMA is a key factor (Woyciechowski 2006).

Taking into account the rheological properties of concrete mixes, i.e. the maximal diameter of the slump flow and the flow time into the diameter of $500 \mathrm{~mm}$ as well as the air content, the mix with $0.0275 \%$ VMA was found as optimal with respect to self-compacting. It fea- tured the maximal flow of $770 \mathrm{~mm}$, the flow time into the diameter of $500 \mathrm{~mm}-6 \mathrm{~s}$ and the air content $-4.0 \%$.

The time changes of the rheological parameters (Figs 2 and 3), indicate, how long a given SCC mix maintains its properties on the same level. In the case of a long transport time to a construction site this feature is vital in the selection of the SCC mix composition. The analysis of Figs 2 and 3 shows that VMA shortened the time when the mix maintained its initial rheological properties within the assumed self-compacting range. There exists a clear relation between the VMA amount and this time. In the case of the mix with $0.01 \%$ VMA the self-compacting parameters were kept for 105 minutes, for the one with $0.0275 \%$ VMA - about 45 minutes, and for the one with $0.045 \%$ VMA - only about 15 minutes. It was decided that the time during which the concrete mix with $0.01 \%$ VMA preserved satisfactory rheological properties is enough from the point of view of engineering practice. On the other hand, the more than $50 \%$ shorter time for the concrete mix with $0.0275 \%$ VMA still seems to be acceptable but its elongation would be desirable.

The testing results of the vertical segregation resistance (Fig. 4) proved the effectiveness of VMA.

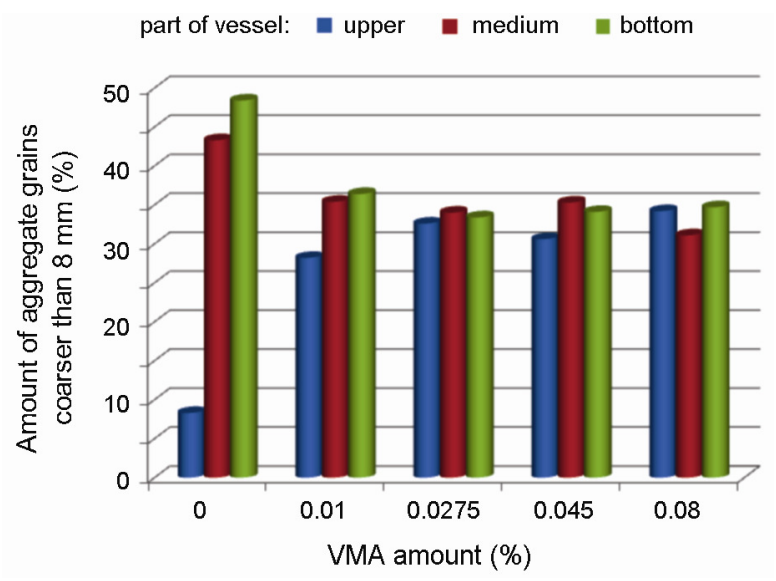

Fig. 4. Segregation resistance of SCC mixes to vertical direction

In the reference mix without VMA the segregation of the components took place. The smallest amount of aggregate was found in the upper section of the testing column. The difference of mass resulted from an inadequate viscosity of the mix which did not feature a network of VMA molecules keeping the same proportions of the mix components in all the sections of the apparatus. Due to the sedimentation process the majority of the missing aggregate was found in the lower section of the column. The difference between the $8 / 16 \mathrm{~mm}$ aggregate fraction amounts for the lower and the upper column sections reached $40 \%$, i.e. twice as much as the limit for which the mix is considered as segregated in the testing method used. On the other hand, the other concrete mixes, even with the smallest amount of VMA $(0.01 \%)$ did not exhibit any signs of segregation. The respective differences were in the range of $1.0-8.2 \%$. It was noticed that higher amounts of VMA resulted in a less visible segregation manifested in smaller differences of the aggregate content for the respective sections of the testing 
column. It is worth emphasising that the segregation resistance plays an important role in the SCC technology because poor segregation means poor deformability and leads to blocking aggregate grains around reinforcement. Moreover, the segregation can cause a high drying shrinkage as well as non uniform compressive strength of concrete (Bui et al. 2002). In the present research shrinkage was not tested but the VMA influence on this property begins to attract a scientific interest. There are some promising results by Gołaszewski and Cygan (2011), concerning plastic shrinkage and drying shrinkage of selfcompacting mortars modified with methylocellulose and copolymer based VMA. They indicate some reduction of shrinkage due to VMA.

The 28-day compressive strength results presented in Table 4 point out that an increase of the VMA amount leads to a decrease of the concrete strength. This fact should probably be attributed to an increase of the air content in the modified mixes (Fig. 5 and Table 4).

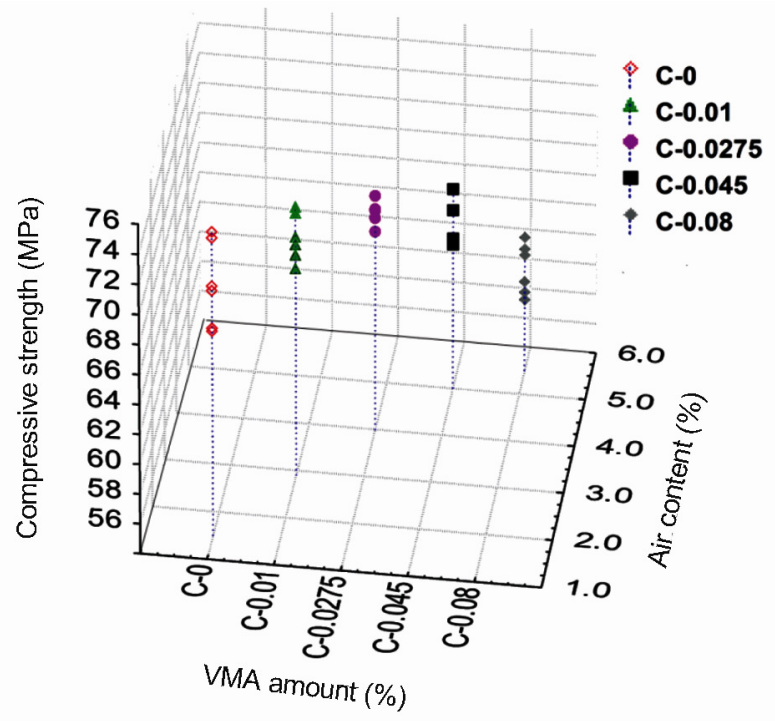

Fig. 5. 28-day compressive strength and air content of SCC in dependence on amount of VMA

Table 4. Air content and compressive strength of SCC

\begin{tabular}{|c|c|c|c|}
\hline \multirow{2}{*}{$\begin{array}{l}\text { Designation } \\
\text { of concrete }\end{array}$} & \multirow{2}{*}{$\begin{array}{c}\text { Air content } \\
(\%)\end{array}$} & \multicolumn{2}{|c|}{ Compressive strength $(\mathrm{MPa})$} \\
\hline & & $\begin{array}{l}\text { Mean } \\
\text { value }\end{array}$ & $\begin{array}{l}\text { Standard } \\
\text { deviation }\end{array}$ \\
\hline $\mathrm{C} 0$ & 1.5 & 70.8 & 2.8 \\
\hline $\mathrm{C} 0.01$ & 2.9 & 70.0 & 1.6 \\
\hline $\mathrm{C} 0.0275$ & 4.0 & 68.3 & 0.9 \\
\hline $\mathrm{C} 0.045$ & 5.0 & 64.8 & 1.5 \\
\hline C0.080 & 5.5 & 60.8 & 1.7 \\
\hline
\end{tabular}

The strength difference between VMA-free concrete and concrete with $0.08 \%$ VMA reached about $10 \mathrm{MPa}$. On the other hand, the strength difference between zero reference level, and $0.0275 \%$ level was insignificant, despite an increase of the air content. It was also confirmed by the Tukey's test, which was carried out when the significance of the VMA amount on the concrete strength was found in the statistical analysis. The para- metric test was used, because two basic conditions were satisfied, i.e. the distribution of particular strength testing results fulfilled the commonly accepted assumption of the normal distribution and the Levene's test (Table 5) proved, that it was impossible to discard the hypothesis of variance homogeneity - p-value was higher than 0.05 . The scatter of particular results was smallest for the level $0.0275 \%$ (Fig. 6).

Table 5. Results of Levene's test

Levene's test of variance homogeneity

Effect of VMA amount on compressive strength

Degrees of freedom (4 and 25) for F statistics

\begin{tabular}{c|c|c|c}
\hline MS Effect & MS Error & F & p-value \\
\hline 1.680222 & 0.787896 & 2.132542 & 0.106533 \\
\hline
\end{tabular}

Note: MS - Mean Squares; F - the F statistics

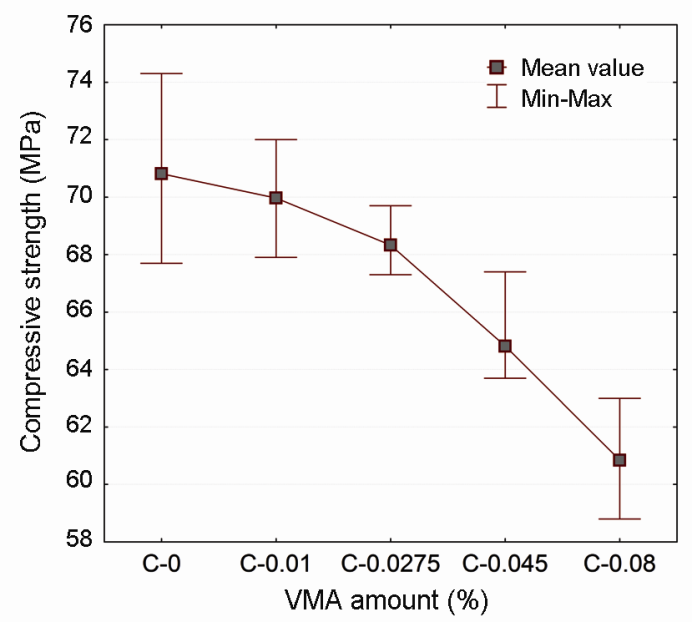

Fig. 6. Results' scatter for 28-day compressive strength at various VMA amounts

Results of the statistical significance based on Tukey's test is demonstrated in Table 6.

Table 6. Results of Tukey's test (symbolically presented)

\begin{tabular}{l|c|c|c|c|c}
\hline $\begin{array}{l}\text { Designation } \\
\text { of concrete }\end{array}$ & $\mathrm{C} 0$ & $\begin{array}{c}\mathrm{C} \\
0.01\end{array}$ & $\begin{array}{c}\mathrm{C} \\
0.0275\end{array}$ & $\begin{array}{c}\mathrm{C} \\
0.045\end{array}$ & $\begin{array}{c}\mathrm{C} \\
0.080\end{array}$ \\
\hline $\mathrm{C} 0$ & & Ins. & Ins. & Sign. & Sign. \\
\hline $\mathrm{C} 0.01$ & Ins. & & Ins. & Sign. & Sign. \\
\hline $\mathrm{C} 0.0275$ & Ins. & Ins. & & Sign. & Sign. \\
\hline $\mathrm{C} 0.045$ & Sign. & Sign. & Sign. & & Sign. \\
\hline $\mathrm{C} 0.080$ & Sign. & Sign. & Sign. & Sign. & \\
\hline
\end{tabular}

Note: Sign. / Ins. - statistically significant / insignificant difference

\section{Conclusions}

1. Viscosity modifying agent (VMA) used in the tests enhanced the internal integrity of the concrete mix. An increase of the VMA amount reduced the fluidity of the mix and the slump flow time became longer, while the self-compacting conditions were satisfied.

2 . The time, during which the rheological parameters of the concrete mix were maintained, decreased with the increasing amount of VMA. 
3. VMA caused a mix aeration, which increased with an increase of the VMA amount.

4. All the concrete mixes with VMA exhibited resistance to the vertical segregation. The maximal homogeneity of this vital property for SCC was achieved in the case of $0.0275 \%$ VMA.

5. The increasing amount of VMA led to a decrease of the 28-day compressive strength of concrete.

6. Taking into account the fresh concrete properties (the rheological parameters, the air content and the segregation resistance) and hardened concrete parameters (homogeneity and the 28-day compressive strength), the optimal VMA dosage of $0.0275 \%$ was selected from the assumed levels.

7. The statistical analysis proved the significance of the VMA amount on concrete compressive strength. This analysis combined with the scatter analysis of particular results enabled to select the optimal level of the VMA amount equal to $0.0275 \%$, which was characterised by an insignificant (proved by Tukey's test) strength loss with respect to the zero level, while the standard deviation was smallest.

\section{Acknowledgments}

The author expresses sincere apreciation to MSc. Sylwester Stankiewicz from Hufgard Poland for providing the viscosity modifying agent and MSc. Honorata Chlebowska from MC - Bauchemie Sroda Wielkopolska Poland for lending the set evaluating resistance of SCC to vertical segregation.

\section{References}

Bui, V. K.; Montgomery, D.; Hinczak, J.; Turner, K. 2002. Rapid testing method for segregation resistance of selfcompacting concrete, Cement and Concrete Research 32(9): 1489-1496.

http://dx.doi.org/10.1016/S0008-8846(02)00811-6

EFNARC 2005. The Guidelines for self-compacting concrete. Specification and use. Surrey, UK: European Federation of Suppliers of Specialist Construction Chemicals (EFNARC), 2005. $63 \mathrm{p}$.

EFNARC 2006. Guidelines for Viscosity Modifying Admixtures for Concrete. Surrey, UK: European Federation of Suppliers of Specialist Construction Chemicals (EFNARC), 2006. 11 p.

Felekoglu, B.; Yardamici, M. Y.; Bardan, B. 2003. A comparative study of the use of mineral and chemical types of viscosity enhancers in self-compacting concrete, in O. Vallevik, I. Niellson (Eds.). Proc. of the $3^{\text {rd }}$ International RILEM Symposium on Self-Compacting Concrete, 17-20 August, 2003, Reykjavik, Island. France, Bagneux: RILEM Publications S.A.R.L. PRO 33, 446-456.

Gołaszewski, J.; Cygan, G. 2008. Wpływ temperatury na urabialność mieszanek betonów samozagęszczalnych [Influence of temperature on workability of fresh selfcompacting concretes], in Proc. of Dni Betonu. Tradycja $i$ Nowoczesność, 13-15 October, 2008, Wisła, Poland. Polski Cement, Kraków, 115-124.

Gołaszewski, J.; Cygan, G. 2010. Wpływ temperatury na działanie domieszek zwiększajacych lepkość zapraw [Influence of temperature on the effectiveness of viscosity modyfing agents in mortars], in Proc. of Dni Betonu. Tradycja i Nowoczesność, 11-13 October, 2010, Wisła, Poland. Polski Cement, Kraków, 625-634.

Gołaszewski, J.; Cygan, G. 2011. Wpływ domieszek zwiększających lepkość na skurcz wczesny zapraw [Influence of VMA admixtures on early shrinkage of cement mortars], Civil and Environmental Engineering 2: 263-266.

Gorzelańczyk, T. 2011. The effect of moisture content on the failure of self-compacting concrete under compression, assessed by means of acoustic methods, Archives of Civil and Mechanical Engineering 11(1): 45-60.

http://dx.doi.org/10.1016/S1644-9665(12)60173-3

Gorzelańczyk, T.; Hoła, J. 2011. Pore structure of selfcompacting concretes made using different superplasticizers, Archives of Civil and Mechanical Engineering 11(3): 611-621. http://dx.doi.org/10.1016/S1644-9665(12)60104-6

Grzesiak, K. 2008. Sposób na ekonomiczny i przyjazny beton samozagęszczalny [Method of obtaining more cost effective and friendly self-compacting concrete (SCC)], in Proc. of Dni Betonu. Tradycja i Nowoczesność, 13-15 October, 2008, Wisła, Poland. Polski Cement, Kraków, $125-130$.

Grabiec, A. M.; Chutek, R. 2008. Cement type and properties of self-compacting concrete, Acta Scientiarum Polonorum. Architectura 7(4): 3-14.

Hibino, M. 2000. Effect of viscosity enhancing agent on selfcompactibility of fresh concrete, in V. M. Malhotra (Ed.). Proc. of the $6^{\text {th }}$ CANMET/ACI International Conference on Superplasticisers and Other Chemical Admixtures in Concrete, 10-13 October, 2000, Niece, France. ACI. SP195-19, 305-320.

Jin, D.; Domone, P. L. 2002. Relationships between the fresh properties of SCC and its mortar component, in Proc. of the $1^{\text {st }}$ North American Conference on the Design and Use of Self-consolidating Concrete, 12-13 November, 2002, Illinois, USA. USA: Hanley-Wood, LLC, 37-42.

Khayat, K.; Ghezal, A. 2003. Effect of viscosity modifying admixture - superplasticizer combination on flow properties of SCC equivalent mortar, in O. Vallevik, I. Niellson (Eds.). Proc. of the $3^{\text {rd }}$ International RILEM Symposium on Self-Compacting Concrete, 17-20 August, 2003, Reykjavik, Island. France, Bagneux: RILEM Publications S.A.R.L. PRO 33, 369-394.

Lachemi, M.; Hossain, K. M. A.; Lambros, V.; Nkinamubanzi, P.-C.; Bouzoubaâ, N. 2004a. Performance of new viscosity modifying admixtures in enhancing the rheological properties of cement paste, Cement and Concrete Research 34(2): $185-193$. http://dx.doi.org/10.1016/S0008-8846(03)00233-3

Lachemi, M.; Hossain, K. M. A.; Lambros, V.; Nkinamubanzi, P.-C.; Bouzoubaâ, N. 2004b. Self-consolidating concrete incorporating new viscosity modifying admixtures, Cement and Concrete Research 34(6): 917-926.

http://dx.doi.org/10.1016/j.cemconres.2003.10.024

Leemann, A.; Winnefeld, F. 2007. The effect of viscosity modifying agents on mortar and concrete, Cement and Concrete Composites 29(5): 341-349.

http://dx.doi.org/10.1016/j.cemconcomp.2007.01.004

Lowke, D.; Wiggrink, K.-H.; Shiessl, P. 2003. A Simple and significant segregation test for SCC, in O. Vallevik, I. Niellson (Eds.). Proc. of the $3^{\text {rd }}$ International RILEM Symposium on Self-Compacting Concrete, 17-20 August, 2003, Reykjavik, Island. France, Bagneux: RILEM Publications S.A.R.L. PRO 33, 356-366. 
Łaźniewska-Piekarczyk, B. 2011. Wpływ rodzaju domieszek stabilizujących lepkość (DSL) na właściwości samozagęszczających się zapraw i betonów [Effect of viscosity stabilizing agents on the properties of self-compacting mortars and concretes], Cement Wapno Beton 1: 44-51.

Łaźniewska-Piekarczyk, B.; Szwabowski, J. 2010. Wpływ rodzaju i zawartości domieszek przeciwspieniających i stabilizujących na niektóre właściwości samozagęszczalnych zapraw cementowych [Influence of type and amount of AFA and VMA admixtures on selected properties of self-compacting cement mortars], in Proc. of Dni Betonu. Tradycja i Nowoczesność, 11-13 October, 2010, Wisła, Poland. Polski Cement, Kraków, 647-666.

Memon, S. A.; Shaikh, M. A.; Akbar, H. 2011. Utilization of rice husk ash as viscosity modifying agent in self compacting concrete, Construction and Building Materials 25(2): 1044-1048.

http://dx.doi.org/10.1016/j.conbuildmat.2010.06.074

Okamura, H.; Ouchi, M. 1999. Self-compacting concrete development. Present use and future, in Á. Skarendhal, Ö. Peterrsson (Eds.). Proc. of the $1^{\text {st }}$ International RILEM Symposium on Self-Compacting Concrete, 13-14 September, 1999, Stockholm, Sweden. France, Bagneux: RILEM Publications, 3-14.
Panesar, D. K.; Shindman, B. 2011. Elastic properties of self consolidating concrete, Construction and Building Materials 25(8): 3334-3344.

http://dx.doi.org/10.1016/j.conbuildmat.2011.03.024

Rols, S.; Ambroise, J.; Péra, J. 1999. Effect of different viscosity agents on the properties of self-leveling concrete, Cement and Concrete Research 29(2): 261-266. http://dx.doi.org/10.1016/S0008-8846(98)00095-7

Szwabowski, J.; Gołaszewski, J. 2010. Kształtowanie urabialności mieszanek betonowych nowej generacji [Fresh concrete workability of the new generation concretes], Inżynieria i Budownictwo 5-6: 268-275.

Umar, A; Al-Tamimi, A. 2011. Influence of Viscosity Modifying Admixture (VMA) on the properties of SCC produced using locally supplied materials in Bahrain, Jordan Journal of Civil Engineering 5(1): 32-49.

Woyciechowski, P. 2006. Domieszki modyfikujące lepkość (VMA) samozagęszczalnych mieszanek betonowych [Viscosity modifying admixtures for self-compacting concretes], in Proc. of Dni Betonu. Tradycja i Nowoczesność, 9-11 October, 2006, Wisła, Poland. Polski Cement, Kraków, 623-633.

Anna M. GRABIEC. PhD, Senior Lecturer in the Department of Theory of Structures and Agricultural Building Engineering at the Faculty of Land Reclamation and Environmental Engineering at the University of Life Sciences, Poznan, Poland. Her research interests include concrete technology, particularly admixtures and additives for concrete. Her research interests are also focused on corrosion of RC structures and lately on the possible use of the recycled concrete aggregate in compliance with environmentally sustainable development. 